\title{
Pathogenic Bacteria Isolated from Personal Cell Phones of Health Care Staff in Iraqi Hospitals
}

\author{
Noor M. Taher \\ Microbiology Department, College of Medicine, University of Fallujah, Fallujah, Iraq.
}

\begin{abstract}
Cell phones are indispensable accessories both professionally and socially, but they also play role as perfect substrate for microorganisms' transitions. Therefor; Health care workers mobile phones are one of the most important vehicles which transfer nosocomial infection agents in particular pathogenic multi-resist bacteria. Thus, this study aims at examining and conducting of cell phones which could play a potential role in the extent of bacterial pathogens mainly nosocomial bacteria in Iraqi hospitals. Therefore, 102 cell phone samples were collected from patients, doctors and Health care staff working in hospital by Sterile cotton swab on the surface of cell phone and directly sited in liquid media. The samples staking on the Blood and MacConkey agar media were used for bacterial species isolation then identified via Vitek 2 Compact ID/AST cards from BioM rieux. Bacteria species were isolated from 93 of the studied cell phones: Coagulase negative Staphylococci epidermidis (28\%), then Escherichia coli (22\%), Klebsiella pneumonia (16\%), Pseudomonas aeruginosa (13\%), Staphylococcus aureus (12\%), Bacilli (5\%), Enterobacter (3\%), and Proteus spp. (1\%). And $80 \%$ of the bacteria are resistant to antibiotics, predominantly the bacteria isolated from Nurse and Doctor phones. This study shows the potential of cell phones to be developed as pathogenic bacteria carriers.
\end{abstract}

Keywords: Mobile, Cellphone, Nosocomial, Bacteria.

\footnotetext{
*Correspondence: noor.m.taher@uofallujah.edu.iq
}

(Received: 02 April 2019; accepted: 19 May 2019)

Citation: Noor M. Taher, Pathogenic Bacteria Isolated from Personal Cell Phones of Health Care Staff in Iraqi Hospitals, J Pure Appl Microbiol., 2019; 13(2):1145-1150. doi: 10.22207/JPAM.13.2.53

(c) The Author(s) 2019. Open Access. This article is distributed under the terms of the Creative Commons Attribution 4.0 International License which permits unrestricted use, sharing, distribution, and reproduction in any medium, provided you give appropriate credit to the original author(s) and the source, provide a link to the Creative Commons license, and indicate if changes were made. 


\section{INTRODUCTION}

A cell phone is a distant personal device, easy to handle, and affordable to everybody. It is the most essential accessory of professional and societal life in the world. Hospital staff cell phones can be easily and rapidly contaminated by microorganisms from the hospital environment, patients, and medical devices, since they use it for a medical dictionary, hand reference for drug, laboratory, and imaging results, and other workrelated issues as they deal with patients having diverse illnesses (Bodena et al., 2019).

In recent years, mortality and morbidity of infections have improved, at least partially due to the increased incidence of antibiotic resistance in both Gram positive and negative bacteria. Regardless of this data, there exists a scarcity of advice provided to either health staff or patients on the use or decontamination of cell phones in hospitals (Brady et al., 2011).

Recent studies about the microorganism transmission between individuals and their close environments have revolutionized our understanding of the microbial ecology of the environment (Lax et al., 2015). The mobile phones have become one of the important devices used for communication in our daily life, and they are generally used almost everywhere.

The cell phones have also been designated to be a reservoir for bacteria. It has been labelled that a cell phone can harbor more bacterial colonization than a man's toilet seat, the sole of a shoe or the door handle (Shahaby et al., 2012), An article in Daily Mail, UK itemized that 'cell phones harbor more microorganisms than a toilet seat'. The warm environment nearby cell phones coupled with its constant handling creates a major breeding ground for growth of microorganisms. Later, they are exactly called as 'technological Petri-dish of thousands of worms' (Jaya Madhuri et al., 2015).

Through each phone call a cell phone comes into close contact with potentially contaminated human body areas such as hands and also portals of entry such as the mouth, nose and ears. As cell phones performance as perfect habitats for microbes to breed, especially in high temperatures and humid conditions (Zakai et al., 2016).
The cell phone used among Health care workers, patients and visitors were the hazard device for transmutation of bacterial infection in the hospital and the community. Health care worker phones may act as reservoirs for microorganisms that could enable the transmission of bacterial isolates from one patient to another in different hospital (Shahlol et al., 2015)

Nowadays, cell phones converted as a critical equipment in our life. Although they are generally kept in bags or pockets, mobile phones are handled often and held close to the face station (Auhim, 2013). Therefore, the present study was investigated and conducted to determine whether cell phones could play a role in the spread of multiresist bacterial pathogens particularly nosocomial bacteria Iraqi Hospitals.

\section{MATERIALS AND METHODS: \\ Study design}

Cross-sectional study was done from November 2018 to March 2019, at the Medical Microbiology Department College of medicine / University of Fallujah. A total of 102 personal cell phones were randomly sampled from Patients, Doctors and Health care staff working in hospital; Samples were collected from: 19 Microbiologists, 21 Nurses, 22 Doctors, 24 Patients, 7 Medical college students and 9 Chemists who were requested to complete a questionnaire list for data collection at the hospital of Fallujah in Iraq. The questionnaire covered variables like: type of cell phone, age, period of using, use it in toilets, using of disinfectants to clean it and the use of cell phones inside the hospital.

Table 1. Distribution of examined populations and growth bacterial patterns

\begin{tabular}{lccc}
\hline $\begin{array}{l}\text { Category } \\
\text { (year) }\end{array}$ & $\begin{array}{c}\text { Number } \\
\text { of Sample }\end{array}$ & Growth & $\begin{array}{c}\text { Contamination } \\
\text { rate (\%) }\end{array}$ \\
\hline $20-29$ & 51 & 49 & 48.0 \\
$30-39$ & 25 & 24 & 23.5 \\
$40-49$ & 19 & 16 & 15.6 \\
More & 7 & 4 & 3.9 \\
than 50 & 102 & 93 & $91 \%$ \\
Total & & & \\
sample & & &
\end{tabular}




\section{Sample collection}

Samples from the mobile phones of all members of the site were collected randomly during routine daily work, and each was asked about sterility applies that is, if he/she ever cleaned his mobile phone or washed his hand after toilet or used it in toilet and the most significant used it during work and left the gloves of when they consuming. A cotton swab rolled over all exposed outer surface of the phones which were used more than two months. Care was taken to make sure that the touch screen, receiver, microphone area and the home button was swabbed, since these areas are most commonly in contact with the tips of fingers, ears and mouth. The Sterile swab dampened with the sterile saline was rotated over the surface of the cell phone then put it in tubes were supplied with $5 \mathrm{ml}$ of Peptone water media and incubated for $18-24$ at $37^{\circ} \mathrm{C}$. Then sampled swabs were streaked on blood agar and MacConkey agar plates then incubated aerobically for $48 \mathrm{~h}$ at $37^{\circ} \mathrm{C}$. The pure bacterial isolations were re-cultured on MacConkey \& Blood agar plates for $24 \mathrm{~h}$ at $37^{\circ} \mathrm{C}$ for colony isolation and morphological identification. After this period, grown colonies were examined in terms of size and shape and Gram staining was performed for each of the grown colonies and diagnosed according to Forbes and his group 2007 (Selim \& Abaza, 2015).

\section{Bacterial identification}

Identification of bacteria done by Vitek 2 Compact ID/AST cards from BioM rieux company, which Reduces hands-on time for enhanced workflow \& rapid reporting; After primary bacteria isolations, there is reduce handling with a simple standardized inoculum Place the inoculum into the VITEK ${ }^{\circledast} 2$ Cassette at the Smart Carrier Station The VITEK ${ }^{\circledR} 2$ Card and bacterial sample are concomitant by barcode, When the Cassette is loaded, the device handles all later steps for incubation and reading.

\section{Statistical analysis}

Data was carried out by SPSS version 16.0 (SPSS Inc., Chicago, IL, USA). Assemblage of results was depending on variables involved in the questionnaire, and the kind of bacteria found.

\section{RESULT AND DISCUSSION}

Bacterial pathogens are colonized on human host and inanimate objects but most people don't realize that bacteria are found on many common objects in the outdoors, in their workplaces and homes (Jaya Madhuri et al., 2015). Cell phones are often used by both healthcare workers and patients as they are an effective means of communication for both categories. A number of recent studies have exposed how cell phones belonging to healthcare workers establish a device on which various microorganisms linked to nosocomial infections can congregate (Bodena et al., 2019; Selim \& Abaza, 2015). Our results confirm the high relationship between the rates of positive tests regarding the colonization of hands and cell phones, detected for all the microorganisms identified.

A nine aerobic bacterial species have been isolated from $93(91 \%)$ of the examined cell phones and the highest rate of isolation bacteria collected from Nurses, doctors, patients, microbiologist, medical colleges student and chemists sequentially, this has been confirmed by the study of Bodena et al which close enough to our rate with $94.2 \%$ (Bodena et al., 2019), Jaya Lakshmi in 2008 with $91.6 \%$ of the samples and Saudi study done by Zakai et al. with $96.2 \%$ of 105 samples (Zakai et al., 2016). This rate more than the percentage of Tiwari et al which was $76.2 \%$ (Tiwari et al., 2016).

Microbes present in hospitals which mainly multi-resistant to antibiotic due to aerosol, gloves contamination and spreading of bacterial contamination by health worker themselves. These organisms replicated rapidly and adhere to any available surface such as cell phone carried by the health-care workers. The problem may become more serious, if $\mathrm{HCW}$ s become a potential source for transfer of these organisms during invasive procedures and may lead to nosocomial infections (Jaya Madhuri et al., 2015).

In this study, the incidence of E.coli isolations which collected from the cell phone surface, may be associated to fecal and patient contamination. Most of the pathogenic bacteria isolated from Nurse and Doctor phones which could be expected result; but none of these pathogenic bacteria were isolated from chemist and undergraduated students' cell phones, probably because the low levels in which pathogens are present on the surface of these devices and they are lesser in direct contact with patients or their specimens. 
These results are similar to Mexican study done by Martinez-Gonzales et al. :2017. Other Iraqi study done by Mohammad in 2017 was found that positive culture in $52 \%$ of samples and higher positive culture found in mobile of technician, followed by doctors (Auhim, 2013).

In the present study, most bacteria isolated were Coagulase negative Staphylococci epidermidis (28\%), then Escherichia coli (22\%), Klebsiella pneumonia (16\%), Pseudomonas aeruginosa (13\%), Staphylococcus aureus (12\%), Bacillus spp. (5\%), Enterobacter spp. (3\%). and Proteus spp. (1\%). The results were in accordance with study done by Tiwari et al demonstrated the most common organism detected was Staphylococcus epidermidis (25.42\%) and E.coli (25.42\%)( Tiwari et al., 2016); While Zakai et al in 2016 found that Coagulase negative Staphylococci epidermidis were the most abundant isolates $68 \%$.

Positive bacteria for Gram stain, Staphylococcus spp. was $40 \%$ from all isolated bacteria, which was also found in studies showed by others (Bodena et al., 2019; Lakshmi \& Lakshmi, 2014) and S.epidermidis was the most predominant and frequent then S.aureus from mobile phones in this study Ulger et al in 2009 which like our results. However, Staphylococci species are normal skin flora, these organisms have the potential to harbor and transfer drug resistance gene among their genera or beyond.

According on environmental circumstances, bacteria could remain infectious agents on cell phone surfaces for days or weeks after being contaminated. In humidity, pathogens may re-activation and colonized the surfaces, transforming a passive reservoir into an active one. Furthermore, formation of biofilm by one bacterial agent can affect the survival of other pathogens on the same surface (Tagoe et al., 2011). Shakir and his colleagues found that samples were collected from 53 cell phones by culturing on media, pathogenic bacteria grow on 44 cultures which mean $83 \%$ of collected phones contaminated. (Shakir et al., 2015).

Significantly, we found that no patients in our study have shared a cell phone through their hospitalization period. However, this behave could reduce the possibility of bacterial crosscontamination, many stated that they would share their phone if asked. Therefore, Patients in hospitalization period should be given advice to avoid sharing cell phones with other patients in order to mitigate the potential risk of crosscontamination (Brady et al., 2011).

Nevertheless, consistent with our statistical analysis data, there was no relationship

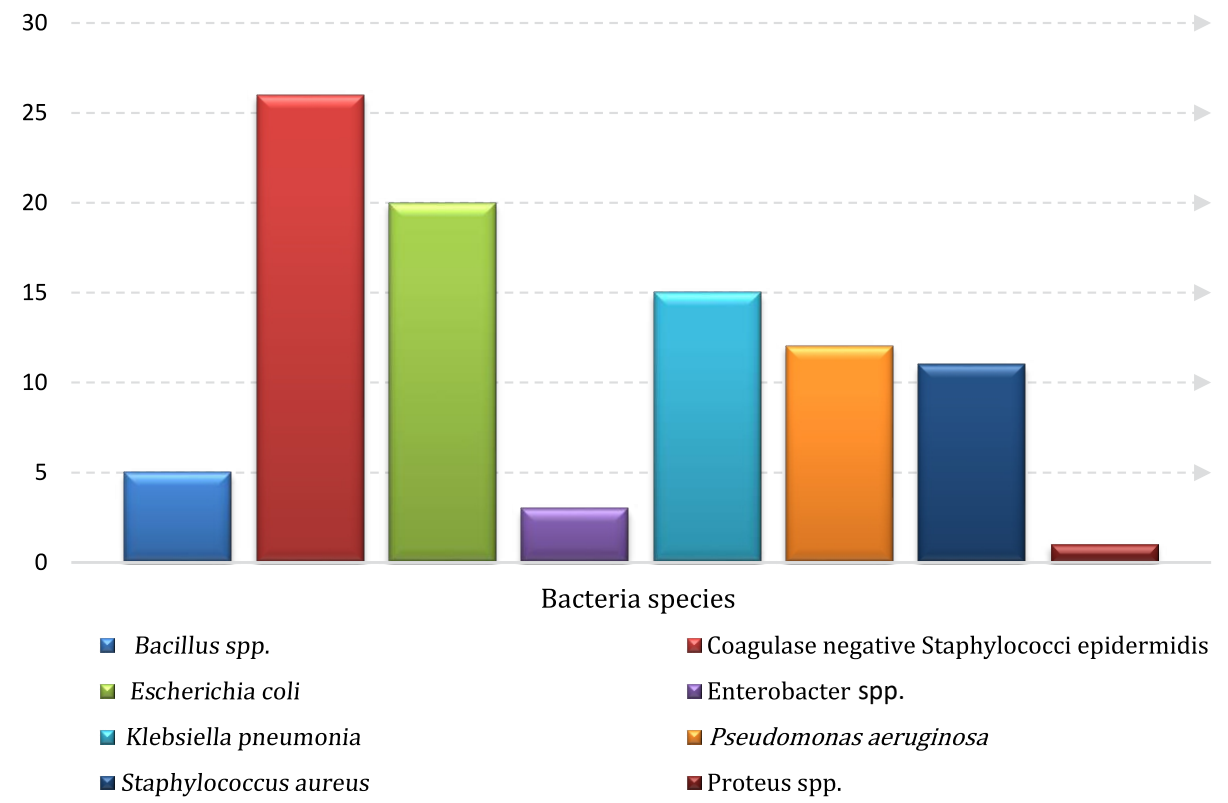

Fig. 1. Bacteria species that isolated from personal cell phones 
between type of phone and usage of phones in toilets and the presence of contamination with bacteria $(p=0.075)$. But there is a correlation between age and type of work jobs because increasing in time of using phone in younger individuals. Previous studies shown that near to $20 \%$ of doctor and nurse cell phones are contaminated with multi-antibiotic resist pathogenic bacteria (Jayalakshmi et al., 2008).

The Present study did not check the efficiency of various chemical disinfectants for cleaning of mobile phones which needs and detecting the resist for more antibiotic to be done in future. The aggregate implication of this result is that the cell phones which are meant to make communication easy are gradually assuming the status of pathogenic agent of disease transmission (Lakshmi \& Lakshmi, 2014).

\section{CONCLUSION}

Cell phones usage in hospital situations carriages a risk of transmission of a pathogenic bacterium of including multidrug-resistant pathogens especially nosocomial bacteria. Therefor; we recommend that Hospital workers and patients are educated by clear strategies and advice on mobile phone protocol and regular cleaning of phones and hand sanitization, above and beyond recommended not to share phones or correlated equipment with other inpatients in order to avoid transmission of bacteria.

\section{ACKNOWLEDGMENTS}

None.

\section{FUNDING}

None.

\section{DATA AVAILABILITY}

All datasets generated or analyzed during this study are included in the manuscript.

\section{ETHICS STATEMENT}

The article does not contain any studies with human participants or animals performed by the author.

\section{REFERENCES}

1. Auhim, Husam Sabah. Bacterial Contamination of Personal Mobile Phones in Iraq. Journal of Chemical,
Biological and Physical Sciences, 2013; 3(4): 26522656.

2. Bodena,Dagne, Teklemariam, Zelelam. Balakrishnan, Senthilkumar. and Tesfa, Tewodros. Bacterial contamination of mobile phones of health professionals in Eastern Ethiopia: Antimicrobial susceptibility and associated factors. Tropical Medicine and Health, 2019; 47(15): 2-10.

3. Brady R.R., Hunt A.C., Visvanathan A., Rodrigues M.A., Graham C., Rae C., Kalima P., Paterson H.M. \& Gibb A.P. Mobile phone technology and hospitalized patients: a cross-sectional surveillance study of bacterial colonization, and patient opinions and behaviours. Clinical Microbiology and Infection, 2011; 17(6): 830-835.

4. Jaya Lakshmi, Appalaraju "Cellphones as Reservoirs of Nosocomial Pathogens" JAPI, 2008; 56, : 388 - 389.

5. Jaya Madhuri R., Saraswathi M., Mahitha G., Bhargavi M., Deepika S., Vijaya Lakshmi G. Bacterial contamination of mobile phones and computers in microbiological laboratories. European Journal of Biotechnology and Bioscience, 2015; 3(9): 51-55.

6. Jayalakshmi J., Appalaraju B., Usha S. Cellphones as reservoirs of nosocomial pathogens. J. Assoc. Physicians India, 2008; 56: 388-9

7. lakshmi M. Swarajya \& Lakshmi B. Mobile phones: Potential Threat in Infection Control. Indian Journal of Basic and Applied Medical Research, 2014; 3(2): 496-500.

8. Lax, Simon, Hampton-Marcell, Jarrad T., Gibbons, Sean M., Colares, Geqrgia Barguil, Smith, Daniel, Eisen, Jonathan A. \& Gilbert, Jack A. Forensic analysis of the microbiome of phones and shoes. Microbiome, 2015; 3(21).

9. Martonez-Gonzzles A.N.E., Solorzano-lbarra F., Cabrera- Doaz E., Gutirrez-Gonzlez P., Martonez-Ch בvez L., Pirez-Montado J.A. \& Martonez-Cבrdenas C. Microbial contamination on cell phones used by undergraduate students. Canadian Journal of Infection Control, 2017; 32(4): 211-216.

10. Selim Heba Sayed \& Abaza Amani Farouk. Microbial contamination of mobile phones in a health care setting in Alexandria, Egypt. GMS Hygiene and Infection Control, 2015; 10: ISSN 2196-5226.

11. Shahaby A.F., Awad N.S., El-Tarras A.E. \& Bahobial A.S. Mobile phone as potential reservoirs of bacterial pathogens. African Journal of Biotechnology, 2012; 11(92): 15896-15904.

12. Shahlol Aisha M.A., Khalifallah Hind M. \& Shahlol Elham M.A. Bacterial contamination of Mobile phones and Hands of Health care workers in Sabha Medical Center Hospital, Fazzan Area in Southwestern of LIBYA. International Journal of Current Research in Medical Sciences, 2015; 1(4) ISSN: 2454-5716:1-8.

13. Shakir Irshad A., Patel Nirav H., Chamberland Robin R. \& Kaar Scott G. Investigation of Cell Phones as a Potential Source of Bacterial Contamination in the Operating Room; The Journal of Bone And Joint Surgery, 2015; 97(3): 225-231.

14. Tagoe D. N., Gyande V.K.\& Ansah E.O. Bacterial Contamination of Mobile Phones:When Your Mobile Phone Could Transmit More Than Just a Call. Article 
URL: http://www.webmedcentral. com/article_ view/2294, 2011; 2(10): ISSN 2046-1690.

15. Tiwari Akanksha, Ankola 1, Anil V., Mishra, Harshita \& Kakkar Mayank. Assessment of Bacterial Contamination in Cellular Phones of Dental Professionals Working in A Dental Institution in Belgaum City - A Cross Sectional Study; Medico Research Chronicles, 2016; 3(3): 266273.

16. Ulger Fatma, Esen Saban, Dilek Ahmet, Yanik Keramettin, Gunaydin Murat \& Leblebicioglu, Hakan.
Are we aware how contaminated our mobile phones with nosocomial pathogens?. Annals of Clinical Microbiology and Antimicrobials - BioMed Central, 2009; 8(7): 1-4.

17. Zakai Shadi, Mashat Abdullah, Abumohssin Abdulmalik, Samarkandi Ahmad, Almaghrabi Basim, Barradah Hesham \& Jiman-Fatani, Asif. Bacterial contamination of cell phones of medical students at King Abdulaziz University, Jeddah, Saudi Arabia. Journal of Microscopy and Ultrastructure, 2016; 143-146. 